BASIC PHYSICS AND TECHNOLOGY OF MEDICAL DIAGNOSTIC ULTRASOUND 
In memory of my late father and in honour of my dear mother 


\section{BASIC PHYSICS AND TECHNOLOGY OF MEDICAL DIAGNOSTIC ULTRASOUND}

MATTHEW HUSSEY, PhD, FInstP

Head, Physics Department, Dublin Institute of Technology

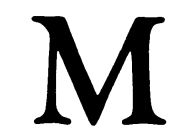

MACMILLAN 
(C) Matthew Hussey 1985

All rights reserved. No part of this publication may be reproduced or transmitted, in any form or by any means, without permission

First published 1985 by

Higher and Further Education Division

MACMILLAN PUBLISHERS LTD

London and Basingstoke

Companies and representatives throughout the world

British Library Cataloguing in Publication Data

Hussey, Matthew

Basic physics and technology of medical

diagnostic ultrasound.

1. Diagnosis, Ultrasonic

I. Title

616.07'543 RC78.7.U4

ISBN 978-0-333-36605-9

DOI 10.1007/978-1-349-17737-0

Filmset in Monophoto Times New Roman by

Latimer Trend \& Company Ltd, Plymouth 


\section{Contents}

Preface $\quad$ x

Acknowledgements xi

1 The Scope of Medical Diagnostic Ultrasound 1

1.1 Introduction and Objectives 1

$\begin{array}{lll}1.2 & \text { Basic Features of Ultrasound } & 2\end{array}$

1.3 Range of Uses of Diagnostic Ultrasound 4

1.4 Why Ultrasound Methods are Being Increasingly Used 5

$\begin{array}{ll}1.5 & \text { Aims and Standard of this Book }\end{array}$

$\begin{array}{ll}1.6 & \text { Quantities and their Units }\end{array}$

$\begin{array}{lll}1.7 & \text { Bibliography } & 7\end{array}$

2 Basic Features of Ultrasound Propagation 12

$\begin{array}{ll}2.1 & \text { Introduction and Objectives } \\ & 12\end{array}$

$\begin{array}{ll}2.2 \text { Sound Waves } & 12\end{array}$

$\begin{array}{ll}2.3 \text { Ultrasound } & 17\end{array}$

$\begin{array}{ll}2.4 \text { Decibel }(\mathrm{dB}) \text { Scale } & 18\end{array}$

2.5 Specular Reflection and Refraction at Boundaries 19

$\begin{array}{lll}2.6 & \text { Scattering } & 23\end{array}$

$\begin{array}{lll}2.7 & \text { Absorption } & 23\end{array}$

$\begin{array}{ll}2.8 \text { Attenuation } & 24\end{array}$

2.9 Bibliography 28

3 Generating and Detecting Ultrasound 29

$\begin{array}{lll}3.1 & \text { Introduction and Objectives } & 29\end{array}$

$\begin{array}{lll}3.2 & \text { Piezoelectric Effect } & 30\end{array}$

3.3 Piezoelectric Materials $\quad 31$

3.4 Single-element Transducer $\quad 32$ 
$\begin{array}{lll}3.5 & \text { Circular Ultrasound Beam } & 35\end{array}$

$\begin{array}{lll}3.6 & \text { Focussing } & 38\end{array}$

3.7 Continuous Wave Excitation of Transducer 40

3.8 Pulsed Excitation of Transducer 40

3.9 Rectangular Ultrasound Beam 42

3.10 Multi-element Array Transducers $\quad 42$

3.11 Piezoelectric Transducers as Detectors of Ultrasound 44

3.12 Other Detectors of Ultrasound 45

3.13 Care of Transducer Probes $\quad 47$

3.14 Testing of Transducers $\quad 47$

$\begin{array}{ll}3.15 \text { Bibliography } & 49\end{array}$

$4 \quad$ A-Mode Scanning Instruments $\quad 51$

4.1 Introduction and Objectives 51

4.2 Pulse-echo Ranging 51

4.3 Average Speed of Propagation 53

4.4 The A-Mode Display 54

4.5 Schematic Outline of A-Mode Instrument 55

4.6 Operator Controls on Instrument 59

$\begin{array}{lll}4.7 & \text { Caliper Measurements } & 63\end{array}$

4.8 Axial Resolution $\quad 63$

$\begin{array}{ll}4.9 \text { Sensitivity } & 65\end{array}$

$\begin{array}{ll}4.10 \text { Artifacts } & 65\end{array}$

4.11 Clinical Applications $\quad 68$

4.12 Permanent Records of Examinations $\quad 69$

$\begin{array}{ll}4.13 \text { Instrument Performance Checks } & 69\end{array}$

$\begin{array}{ll}4.14 \text { Limitations } & 72\end{array}$

$\begin{array}{ll}4.15 \text { Bibliography } & 73\end{array}$

5 Motion (M-) Mode Scanning Instruments 74

$\begin{array}{lll}5.1 & \text { Introduction and Objectives } & 74\end{array}$

$\begin{array}{lll}5.2 & \text { M-Mode Display } & 74\end{array}$

$\begin{array}{lll}5.3 & \text { Schematic Outline of the Instrument } & 75\end{array}$

$\begin{array}{lll}5.4 & \text { Recording of Examinations } & 77\end{array}$

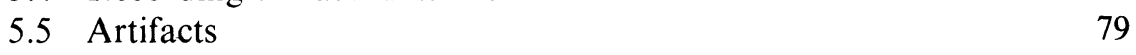

5.6 Instrument Performance Checks $\quad 79$

$\begin{array}{lll}5.7 & \text { Clinical Applications } & 79\end{array}$

$\begin{array}{ll}5.8 \text { Main Limitations } & 80\end{array}$

$\begin{array}{lll}5.9 & \text { Bibliography } & 81\end{array}$ 


\section{CONTENTS}

$\begin{array}{lll}6.1 & \text { Introduction and Objectives } & 83\end{array}$

$\begin{array}{lll}6.2 & \text { B-Mode Display or Image } & 84\end{array}$

6.3 Schematic Outline of the B-Mode Instrument 84

6.4 Patient Position/Image Reference Conventions 88

$\begin{array}{ll}6.5 \text { Bistable Displays } & 90\end{array}$

6.6 Analogue Grey-scale Displays 92

6.7 Digital Grey-scale Displays 95

6.8 Operator Machine Controls 96

6.9 Axial and Lateral Resolutions $\quad 97$

6.10 Artifacts $\quad 99$

6.11 Permanent Records of Images 101

$\begin{array}{ll}6.12 \text { Instrument Performance Checks } & 102\end{array}$

6.13 Contact Scanning and Water Path Delay-line Scanning 104

6.14 Critique of Static B-Mode Imaging in Clinical Applications 105

$\begin{array}{ll}6.15 \text { Bibliography } & 106\end{array}$

7 Dynamic (Real-Time) B-Mode Scanning 108

$\begin{array}{lll}7.1 & \text { Introduction and Objectives } & 108\end{array}$

$\begin{array}{lll}7.2 & \text { Rapid Mechanical Scanning Units } & 109\end{array}$

$\begin{array}{ll}7.3 \text { Multi-element Array Techniques } & 110\end{array}$

$\begin{array}{lll}7.4 & \text { The Multi-element Array Instrument } & 112\end{array}$

$\begin{array}{ll}7.5 & \text { Beam Focussing and Guidance by Phased Arrays } \\ 7.6 & 113\end{array}$

$\begin{array}{lll}7.6 & \text { Problems and Difficulties } & 116\end{array}$

$\begin{array}{lll}\text { 7.7 Permanent Recording of Dynamic Images } & 117\end{array}$

$\begin{array}{lll}7.8 & \text { Instrument Performance Checks } & 118\end{array}$

7.9 General Remarks about Clinical Applications of Dynamic $\begin{array}{ll}\text { B-Mode Units } & 118\end{array}$

$\begin{array}{lr}7.10 \text { Bibliography } & 119\end{array}$

8 Doppler Instrumentation $\quad 120$

$\begin{array}{lll}8.1 & \text { Introduction and Objectives } & 120\end{array}$

$\begin{array}{ll}8.2 \text { Doppler Effect } & 121\end{array}$

8.3 Schematic Outline of Basic Continuous Wave (cw) Doppler $\begin{array}{ll}\text { Instrument } & 123\end{array}$

$\begin{array}{ll}\text { 8.4 Signal Analysis and Recording } & 125\end{array}$

$\begin{array}{ll}\text { 8.5 Directional Doppler Systems } & 128\end{array}$

$\begin{array}{ll}\text { 8.6 Calibration and Performance Checks } & 129\end{array}$

$\begin{array}{ll}\text { 8.7 Clinical Uses and Limitations } & 130\end{array}$

8.8 Schematic Outline of Range-gated Pulsed Doppler Instruments 132

$\begin{array}{ll}8.9 \text { Imaging with Pulsed Doppler Units } & 135\end{array}$ 
8.10 Performance Checks for Pulsed Doppler Instruments 137

8.11 Clinical Uses and Limitations of Pulsed Doppler Instruments 137

8.12 Bibliography

9 Permanent Records of Ultrasound Examinations

9.1 Introduction and Objectives

9.2 Human Visual Perception

9.3 Images and Image Science

9.4 Cameras

9.5 Films and Developing

9.6 Properties of Transparency Film

9.7 Positive Transparencies and Prints

9.8 'Instant' Photography

9.9 Oscilloscope Photography

9.10 Photography of Grey-scale Images from Oscilloscope Displays

9.11 Electronic Image Storage Devices

9.12 Chart Recording

9.13 Recording of Auditory Signals

9.14 Bibliography

10 Special Instruments and New Topics

10.1 Introduction and Objectives

10.2 PPI-Mode Scanning Instruments

10.3 C-Mode Techniques

10.4 Through-transmission Computerised Reconstruction Tomography

$\begin{array}{ll}10.5 \text { Small Organ Scanning Instruments } & 170\end{array}$

$\begin{array}{lll}10.6 & \text { Breast Scanning Units } & 171\end{array}$

$\begin{array}{lll}10.7 & \text { Special Transducers } & 172\end{array}$

$\begin{array}{ll}10.8 \text { Automatic Scanning } & 174\end{array}$

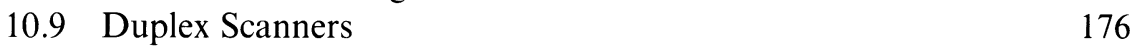

$\begin{array}{ll}10.10 \text { Tissue Characterisation } & 177\end{array}$

$\begin{array}{ll}10.11 \text { Tissue-equivalent Phantoms } & 179\end{array}$

$\begin{array}{ll}10.12 \text { Instrument Standardisation } & 182\end{array}$

$\begin{array}{lr}10.13 \text { Bibliography } & 182\end{array}$

11 Safety of Diagnostic Ultrasound 184

$\begin{array}{llr}11.1 & \text { Introduction and Objectives } & 184\end{array}$ 
11.2 General Physical Effects of Ultrasound on Living Tissues 184

$\begin{array}{lll}11.3 & \text { Bioeffects and Thresholds } & 187\end{array}$

$\begin{array}{lll}11.4 & \text { Epidemiology } & 190\end{array}$

$\begin{array}{ll}11.5 & \text { Diagnostic Ultrasound Dosimetry }\end{array}$

11.6 Protection Against Ill Effects of Ultrasound 191

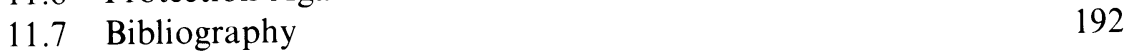

\section{Appendixes}

A : Exponential Decay 194

B: Logarithms 195

C: Mechanical Energy and Vibrations $\quad 197$

D: Heat 201

E: Electricity 202

F: Electronics 206

G: Cathode-ray Oscilloscope $\quad 209$

$\mathrm{H}$ : Storage Oscilloscope 213

$\begin{array}{ll}\text { I : TV Monitor } & 215\end{array}$

J: Analogue Scan Converters 218

K : Digital Computers 223

L: Digital Scan Converter 227

$\begin{array}{ll}\text { Index } & 233\end{array}$ 


\section{Preface}

The applications of medical diagnostic ultrasound grow year by year. New diagnoses are described in the literature and novel instruments are developed and marketed.

For the clinicians involved and for their clinical/technical assistants, a knowledge of (a) the basic concepts of ultrasound physics, (b) the interactions possible between ultrasound and tissues and (c) the range of technologies actually harnessed in ultrasound instruments, is of central importance.

These practitioners of diagnostic ultrasound, in radiology, obstetrics, cardiology, neurology, ophthalmology and various other medical disciplines, all need a systematic exposition of these ideas, well-rooted in their background knowledge of physics and physiology but transcending the level provided in manufacturers' manuals for instruments.

The aim of this book is to provide this framework and this groundwork. An elementary acquaintance with general physics is assumed. Only a minimal knowledge of mathematics is required. A clinical involvement with diagnostic ultrasound is, however, fundamental.

After studying this book, the ultrasound practitioner should be much better able to understand the various clinical instruments and the practical methods for using them. More thorough and more fruitful diagnoses of diseases should result.

But other advantages should also emerge: better informed choices of new instruments; more rounded and critical evaluation of new technologies; and more efficient expenditure of limited health-care resources.

Furthermore after studying this book, the student should be capable of delving into the clinical ultrasound literature, both books and periodicals, and should be able to develop his/her career as the field of diagnostic ultrasound evolves.

Dublin, 1984

M.H. 


\section{Acknowledgements}

I wish to thank sincerely the following, who helped to complete this work:

Ms Gerardine Keating, who typed the manuscript.

Ms Joan C. Miller, who supplied all of the B-mode images.

Mr Gerard King, who supplied the M-mode recordings.

Mr James Robinson, who produced the prints of all of the images.

The author's many students of medical ultrasound, who over the past decade have helped to clarify the need for, and the approach adopted, in this book. 